\title{
Petrography and Mineral Chemistry of the Almanden Garnet, and Implication for Kelyphite Texture in the Miocene Alkaline Basaltic Rocks North East Jordan
}

\author{
Ibrahim Ahmad Ali Bany Yaseen \\ Institute of Earth and Environmental Sciences, Al-Albayt University, Al-Mafraq, Jordan \\ Email: ibanyyaseen@yahoo.com
}

Received December 5, 2013; revised January 4, 2014; accepted February 3, 2014

Copyright (C) 2014 Ibrahim Ahmad Ali Bany Yaseen. This is an open access article distributed under the Creative Commons Attribution License, which permits unrestricted use, distribution, and reproduction in any medium, provided the original work is properly cited. In accordance of the Creative Commons Attribution License all Copyrights (C) 2014 are reserved for SCIRP and the owner of the intellectual property Ibrahim Ahmad Ali Bany Yaseen. All Copyright (C) 2014 are guarded by law and by SCIRP as a guardian.

\begin{abstract}
The Miocene alkali basaltic rocks cover the northeastern part of Jordan, within Harrat Al-Shaam plateau. The volcanic concentrated along the Dead Sea boundary and spread around the north east of Jordan area, and was considered as interplat volcanic field in Jordan. The volcanic basalt is associated with xenoliths fragmental rocks or xenocryst minerals. Nine samples were collected from the study area and analyzed for XRD, XRF and SEM. These samples presented the xenoliths rocks and minerals existing in the study area. This study is focused on the garnet and pyroxene xenoliths minerals in Tulayl Al-Hasna area within Ufayhim Formation. Hand samples are characterized by coarse aggregates of garnets up to $(2 \mathrm{~cm}$ in diameter) with dark brown to red color, and highly fresh fractures. Also, the pyroxene $(<1.5 \mathrm{~cm})$ with gray to dark green color, and the olivine (range $3-4 \mathrm{~mm})$ are pale green to dark green and pale yellowish color. In thin sections, plagioclase phenocryst in the garnet presented corona texture. In addition, garnet surrounded by orthopyroxene refers to kelyphite texture. There are two types of kelyphite texture fibers and radial as shown in Scanning Electron Microscope photomicrograph. The mineralogical analyses of garnet for X-Ray Diffraction are composed of almandine, pyrope and majorite. The existence of minerals reflects the high pressure and temperature of the upper mantle origin. The chemical analysis showed the average composition of garnet as follow (Alm 42.78, Pyro 41.04, Gross 16.18), pyroxene (Wo 16.90, Fs 20.37, En 62.73). This referred to presentation of the following elements $\mathrm{Mg}, \mathrm{Fe}$ and $\mathrm{Ca}$ in the garnet. As a result, the basaltic garnet xenoliths were from shallow lithosphere mantle origin.
\end{abstract}

\section{KEYWORDS}

Almandine Garnet; Kelyphite; Volcanic Xenoliths; Tulayl Al-Hasna; Jordan

\section{Introduction}

Almandine garnet is considered as a relatively rare mineral in the volcanic alkali basalt. The rarity may be due to under the restricted condition, such as garnet which can be formed in hydrous mantle sources, with high-pressure crystallization from hydrous Al-rich magma [1], and geodynamic setting tensional stress field, which rapidly ascending garnet bearing melts. According to [2] almandine can be liquid or near liquid mineral in silica magma at high pressure (9 - $18 \mathrm{Kbar})$. Experimental studies of [3-8] show that Ca- rich ( $\mathrm{Ca}>4 \mathrm{wt} \%)$ and $(\mathrm{Mn}<4 \mathrm{wt} \%)$ almandine crystallize from hydrous andesitic magmas at relatively high pressure ( $>7 \mathrm{kbar})$ and temperature at $900^{\circ} \mathrm{C}-950^{\circ} \mathrm{C}$. [5] suggested that the grassular and spessartine contents of almandine are sensitive to pressure and temperature conditions. The grassular content of garnet increases with increasing pressure, whereas a higher Mn content stabilizes garnet at shallower depths, if (Mn > 4 wt\%) almandine can be crystallized from silica liquids at $\leq 5$ kbar [1]. Bearing $\mathrm{CaO}$ in almandine garnet indicates unstable garnet at low pressure [6], and the chemistry of almandine garnet indicates petrogentic of this mineral in volcanic rocks [1]. Primary Ca bearing almandine in volcanic rocks has been rapid ascent of host magma by a tensional stress field $[9,10]$. 
Mineralogy of the xenoliths garnet is associated with and combination of a few minerals with pyroxene (clinopyroxene, orthopyroxene), olivine and spinal in the mantle at high pressure and temperature [11]. These minerals are different modal and chemical variation with major constituents, pyroxenite (clinopyroxene + orthopyroxene \pm garnet), eclogite (garnet + clinopyroxene), iherzolite (olivine + clinopyroxene + orthopyroxene \pm garnet), harzburgite (olivine + orthopyroxene) and spinal lherzolite (olivine, clinopyroxene, orthopyroxene, spinal and phologopite) [12-14]. Rocks exit in mantle with ultramafic bodies being fragmented and transported to the earth surface as xenoliths by volcanic activity. Xenoliths provide invaluable insights to temperature, pressure, crystallization, fractionation, exsolution, phase changes and partial melting in the upper mantle [15-17].

The mantle xenoliths are variable amounts of ultramafic xenoliths and xenocrysts; these xenoliths are inclusions in mafic to ultramafic or metamorphic rocks, such as garnet and clinopyroxene, which are formed at high pressure and temperature $[16,18,19]$. In Jordan, Garnet occurs mainly in Wadi Abu Burqa metasediments (garnet schist) in Pre Cambrian Aqaba and Araba Complexes [20,21], and occurs as a rare crustal xenolith within the volcanic rocks in the North East Jordan (Harrat Al-Shaam) area. Many authors have documented and discovered the ultramafic xenoliths in jabal Aritain north east Jordan, and report the composition of the basaltic xenoliths includes (garnet, plagioclase, olivine, срx, opx and spinal) respectively [22-26]. Three types of mineral xenoliths were investigated in garnet, pyroxene and olivine at Tlul Esh Shahba area [27]. Spinal lherzolite xenoliths were reported in jabal Al-Harida [14].

The xenoliths are documented belonging to the Cenozoic continental basaltic rocks (Miocene to Holocene-Pleistocene age), in North East Jordan which is the northern extension of the North Arabian Volcanic Province. The Azraq-Sirhan Graben that is parallel to the axis of the Red Sea and truncated at the Dead Sea Transform Fault (DTF) $[21,28]$ underlies the province. The xenoliths in basaltic rocks distinguished in the study area (Tulayl AlHasna), with coarse grained, equigranular fragmental, composite of garnet, pyroxene, olivine and plagioclase.

Almandine garnet occurs in Cenozoic alkali volcanic rocks at Harrat Ash Shaam area and relatively common in study area Tulayl Al-Hasna (TAH) northeast Jordan (Figure 1). The geodynamic setting of the garnet and relation between volcanism and tectonic events in this region have been explained in this study. The aims of this work are to: 1) Explain the bearing garnet in the study area, 2) Describe the occurrence of the garnet and associated minerals in the formation of the basaltic volcanoes, 3) Shed light on the mineralogy, petrography and minerals chemistry of the xenoliths, 4) Implicate the

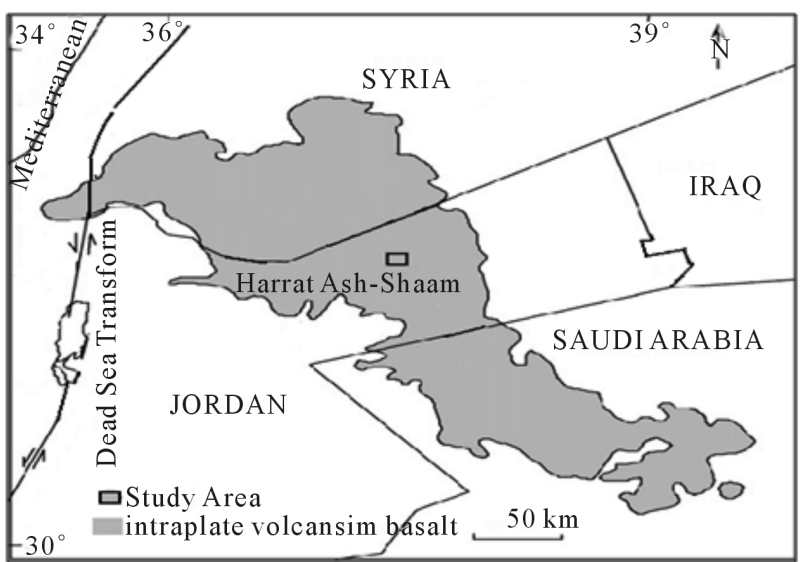

Figure 1. Location map shows the study area, and Harrat Ash Shaam Basalt Plateau through within Jordan, (after NRA, 2006 Jordan).

kelyphite texture growth with the garnet minerals in the alkaline volcanic rocks at Tulayl Al Hasna northeast Jordan.

\section{Geological Setting}

The volcanism in Jordan occurs as sporadic volcanic centers (vents) along the eastern side of the Dead Sea Plate boundary and extensive interpolate volcanic field to the north east of Jordan [21]. The volcanism is associated with continental rifting and inception of the Dead Sea boundary, and associated between magmatism and tectonic activities, that have produced melt generation into fissure system [29]. The volcanic in Jordan investigated by [30], and reported similar to alkaline Arabia interpolates volcanic fields, erupted within the main fissure systems. The fissures trend to east-west, along the eastern margin of the Dead Sea Rift, on the large basaltic plateau, fissures trend NW-SE direction [31]. The volcanism started probably during the middle to late Miocene and recent (13 - $8 \mathrm{Ma}$ ) [29,32-36]. The volcanism field extends from Syria through Jordan and into Saudi Arabia (Harrat Al-Shaam) more than 46,000 $\mathrm{km}^{2}$ which covers $11,400 \mathrm{~km}^{2}$ in Jordan (Figure 1) [37]. The volcanic field comprises a series of horizontal lava flows, numerous scoria cones, extensional faults and large fissure eruptions from dykes and numerous vents along the basaltic plateau of northeast Jordan [31]. The study area cover a part of volcanic vent, location ( $32^{\circ} 20^{\prime} 582^{\prime \prime} \mathrm{N}-32^{\circ} 20^{\prime} 586 " \mathrm{~N}$ and $37^{\circ} 30^{\prime} 553^{\prime \prime} \mathrm{E}-37^{\circ} 30^{\prime} 560^{\prime \prime} \mathrm{E}$ ) in the northeast Jordan (Figure 2).

The basaltic province cover the north east Jordan was subdivided into five super-groups; Wisad, Safawi, Asfar, Rimah and Bishriyya [38-42]. The Safawi group is Oligocene to Miocene in age, represented by flood lava at Ali Doloritic Trachytic basalt (AL) Formation and Abed Olivine Phyric Basalt (AOB) associated with dykes [31]. 
Asfar group is late Miocene to Pliocene, comprises two volcanic Formations, Ufayhim Xenolithic Basalt (UM) and Hashmiyya Aphanitic Basalt (HAB). Rimah group is Holocene-Pleistocene in age, it subdivided into two volcanic formations, Hassan Scoriaceous (HN) and Aritayn Volcanic clastic (AT) (Figure 2). The lithological description of the formation cover the study area are shown in (Table 1).

\section{Analytical Techniques}

Nine xenoliths fragmental rocks and xenocryst minerals were collected from the study area. Five xenocryst of the garnet minerals (G2, G4, G5, G7 and G9), four samples for xenolith of pyroxene minerals (G1, G3, G6 and G8), and six rock samples of the different formation from Tulaylat al Hasna (TAH) area. Bulk samples of the xenolith were analyzed by X-Ray diffraction (XRD) using a Phil-

Table 1. Lithological description of the formation caver the study area.

\begin{tabular}{|c|c|c|}
\hline Groups & Formation & Description \\
\hline \multirow[b]{2}{*}{ Safawi } & Ali Dolorite Trachytic Basalt (AL) & $\begin{array}{l}\text { pale to light brown color, Phaneritic (medium to coarse grained) equigranular crystal of } \\
\text { plagioclase, olivine and pyroxene. Pale grey to white oriented crystal of plagioclase from } 0.2 \\
\text { - } 1.0 \mathrm{~cm} \text { in length with yellowish green to honey colored, clusters of anhedral to } \\
\text { subhedrall, olivine crystals altered to iddingsite, blackish green pyroxene are present. }\end{array}$ \\
\hline & Abed Olivine Phyric Basalt (AOB) & $\begin{array}{l}\text { The basaltic formation characterized by a hummocky, rough and blocky surface, } \\
\text { melanocratic, grey to dark-grey in color, holocrystalline and medium grained with } \\
\text { Porphyritic texture. Phenocryst composite of olivine alteration to iddingsite. Very fine } \\
\text { grained of plagioclase crystals was observed in a hand specimen with aid of a lens with } \\
\text { intergranular texture. }\end{array}$ \\
\hline \multirow[t]{2}{*}{ Asfar } & Ufayhim Xenolithic Basalt (UM) & $\begin{array}{l}\text { The formation composed of dark color minerals, it is consisting of melanocratic, dark and } \\
\text { grey to fine grained basalt, and have a distinctive morphological pattern. The basalt of this } \\
\text { formation is characterized by the presence of large amounts of mantle derived olivine } \\
\text { xenoliths with green to pale yellowish to orange color; pyroxene dark to dark green color } \\
\text { and brown to dark red garnet minerals with highly fracture. The clastic fragment xenoliths of } \\
\text { this formation in the study area, represented by different color minerals and composition, } \\
\text { e.g. olivine, pyroxene and dark red garnet minerals. }\end{array}$ \\
\hline & Hashmiyya Aphanitic Basalt (HAB) & $\begin{array}{c}\text { The formation composed of gray to black fine grained holocrystalline basalt contains } \\
\text { xenoliths of olivine minerals. }\end{array}$ \\
\hline \multirow{2}{*}{ Rimah } & Hassan Scoriaceous (HN) & $\begin{array}{l}\text { The formation is a poorly bedded, coarse to medium grained, red to brown scoria, bombs and } \\
\text { blocks with large scoriaceous fragments. }\end{array}$ \\
\hline & Aritayn Volcaniclastic (AT) & $\begin{array}{l}\text { The formation consists of bedded with poorly cemented and composite of fine grained ash } \\
\text { deposits with variable colors and angular to spherical lapilli. }\end{array}$ \\
\hline
\end{tabular}
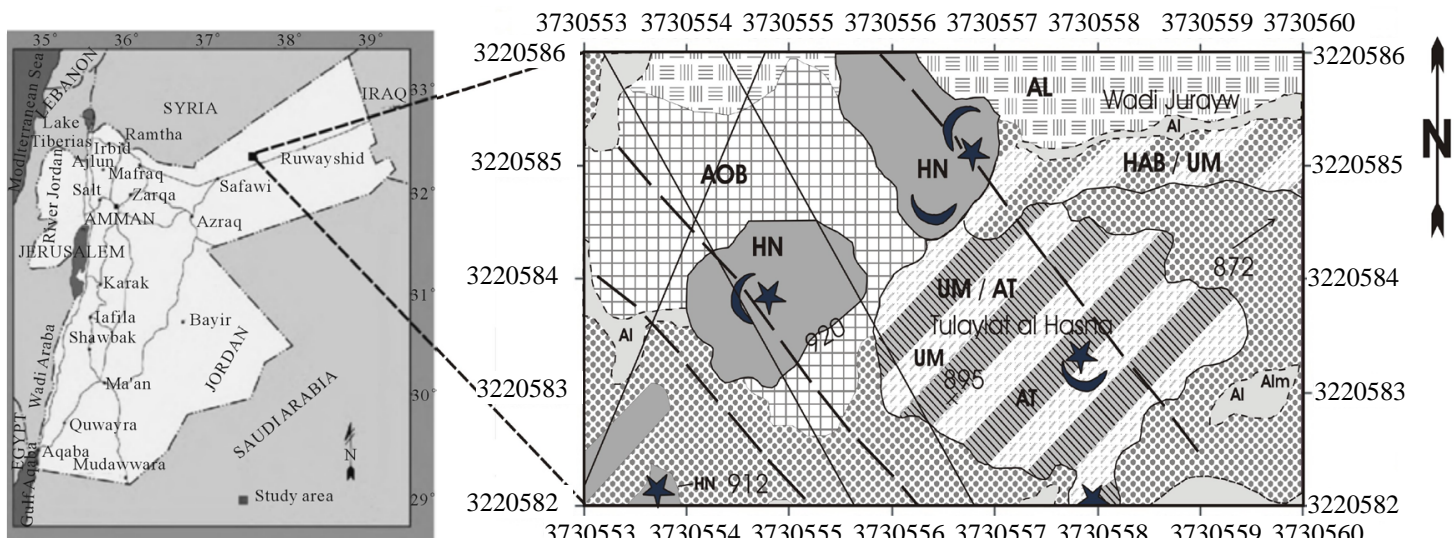

37305533730554373055537305563730557373055837305593730560

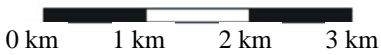

Abed Olivine Basalt (AOB)

Hassan Scoriaceous (HN)

Hashmiyya APhanitic Basalt (HAB)

Ufayhim Xenolithic Basalt (UM)
Mim Aritayn Volcaniclastic (AT)

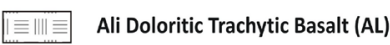

Alluvium Wadi Sediment (AL),Alluvium Mudfalt (Alm)

Volcanic Vent

Figure 2. Geological map of the study area. 
lips difractometer with $\mathrm{Cu} \mathrm{K} \alpha$ radiation in the range from $3^{\circ}$ to $90^{\circ} 2 \theta$ at $\mathrm{Al}$ al-Bayt University. The analyses used to assist in the identification of the mineral present in the xenoliths and to augment the petrographic analyses. Five samples (G1 - G5) examined using Scanning Electron Microscope (SEM)-FEI, Model:Quanta-600. SEM was used to identified the microstructure and investigate the nature of minerals microxture relationship. The chemical analyses of major elements of the samples were determined on fused glass discs-like pellet (bead), using a Phillips X-Ray Florescence Spectrometry (XRF) Majex PW-2424 Model at Al al-Bayt University. Added 2 gm powder samples, mixed with $8 \mathrm{gm}$ lithium tetra borate, and fused in platinum crucibles over gas burners $\left(1000^{\circ} \mathrm{C}\right)$ for one hour. Melts poured into a mold creating glass disks. The Loss On Ignition (LOI) was determined by weight lost after melting at $1000^{\circ} \mathrm{C}$. Thin sections were prepared at the University of Jordan and examined under Binocular Stereomicroscope and polarizer microscopes at petrography unit, Natural Resources Authority (NRA).

The chemical analyses of garnet and pyroxene calculated in mole percent employed by $[43,44]$ formulation. The analyses for garnet include mole percent of grossular (Gross, $\mathrm{Ca}_{3} \mathrm{Al}_{2} \mathrm{Si}_{3} \mathrm{O}_{12}$ ), pyrope (Pyr, $\mathrm{Mg}_{3} \mathrm{Al}_{2} \mathrm{Si}_{3} \mathrm{O}_{12}$ ) and almandine ( $\mathrm{Alm}, \mathrm{Fe}_{3} \mathrm{Al}_{2} \mathrm{Si}_{3} \mathrm{O}_{12}$ ):

$$
\begin{gathered}
\text { Gross }=100 \times[\mathrm{Ca} /(\mathrm{Ca}+\mathrm{Mg}+\mathrm{Fe})], \\
\text { Pyr }=100 \times[\mathrm{Mg} /(\mathrm{Ca}+\mathrm{Mg}+\mathrm{Fe})],
\end{gathered}
$$

and

$$
\mathrm{Alm}=100 \times[\mathrm{Fe} /(\mathrm{Ca}+\mathrm{Mg}+\mathrm{Fe})] .
$$

The calculation of pyroxene in mole percent of wollastonite $\left(\mathrm{Wo}_{\mathrm{CaSiO}}\right)$, Enstatite (En, $\left.\mathrm{MgSiO}_{3}\right)$, and Ferrosilite (Fs, $\mathrm{FeSiO}_{3}$ );

and

$$
\begin{aligned}
& \mathrm{Wo}=100 \times[\mathrm{Ca} /(\mathrm{Ca}+\mathrm{Mg}+\mathrm{Fe})], \\
& \mathrm{En}=100 \times[\mathrm{Mg} /(\mathrm{Ca}+\mathrm{Mg}+\mathrm{Fe})],
\end{aligned}
$$

$$
\mathrm{Fs}=100 \times[\mathrm{Fe} /(\mathrm{Ca}+\mathrm{Mg}+\mathrm{Fe})] \text {. }
$$

\section{Results and Discussion}

\subsection{Petrography}

The main mineral composition of the xenoliths Tulayl Al-Hasna olivine, orthpyroxene (opx) clinopyroxene (срx), plagioclase, garnet and spinel, coarse grained, with equigranular and range from $1.5 \times 2 \times 2 \mathrm{~cm}$ in size (Figure 3 ). Hand specimens, garnet xenolith minerals (G2, G4, G5, G7 and G9) are sub hedrall to irregular in shape with average one to two centimeters in diameter (Figures 3(a) and (b)), dark brown to red color and highly fractures. Pyroxene diameter range between 0.5 to $1.5 \mathrm{~cm}$ in size, gray to dark green in color (G2, G6) (Figure 3(e)). Olivine are granular shape, average 3 - $4 \mathrm{~mm}$ in size with pale green to dark green and pale yellowish to honey in

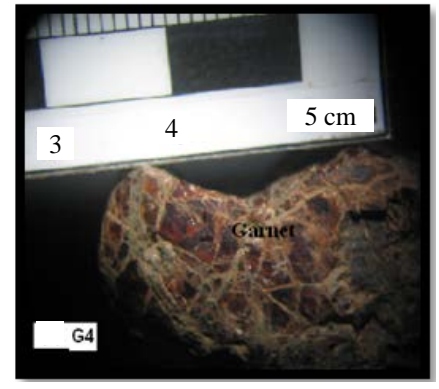

(a)

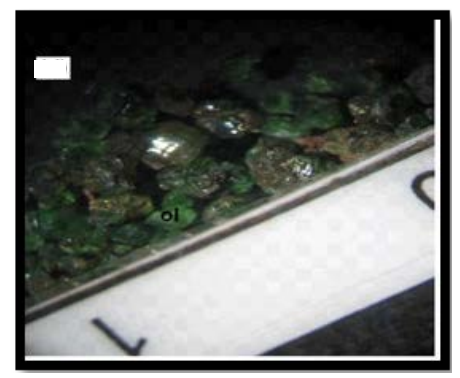

(d)

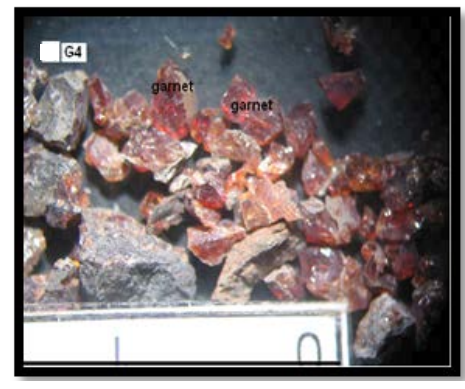

(b)

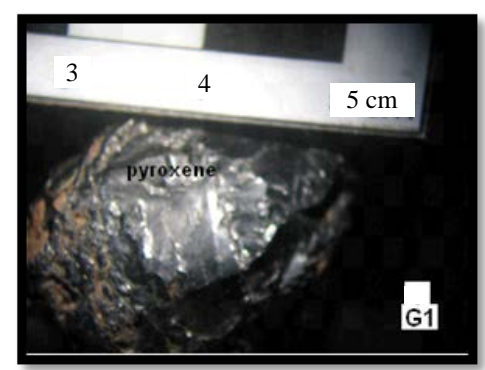

(e)

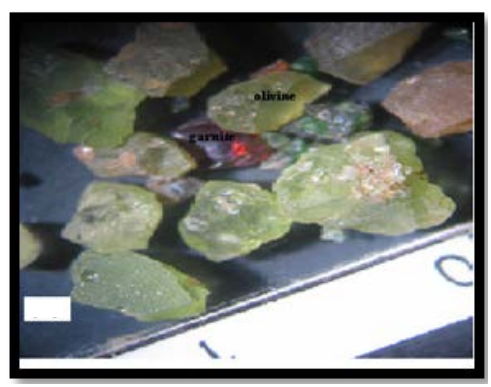

(c)

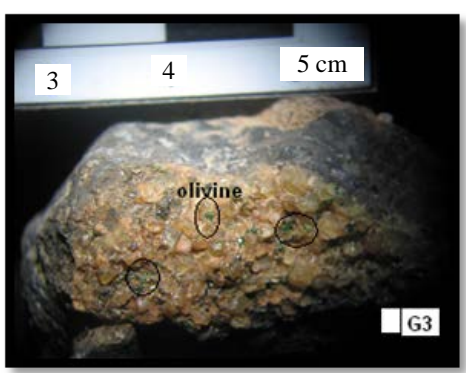

(f)

Figure 3. Photographs show the mineral composition of Ufayhim Xenolithic Basalt under Binocular Stereomicroscope: (a) Garnet minerals, brown to dark red color with highly fractures; (b) Grinding of the garnet minerals; (c) Garnet red and olivine yellowish to green minerals crystal; (d) Olivine with green to pale yellowish crystal; (e) Pyroxene gray to dark green color; (f) Olivine grains with green color. 
color (G3, G8) (Figures 3(c), (d) and (f)).

In thin section, the texture of host rocks for Ufayhim Xenolithic Basalt (UM) formation shows unhedral garnet is variable Porphyritic with medium grained. Plagioclase is the most common phenocryst coexisting with garnet. Corona texture is present, pyroxene surrounded to garnet crystal (Figure 4). These textures formed in reaction between garnet and pyroxene [45]. Other type of corona texture are mad in orthopyroxene surrounded to the garnet crystal (Figure 5), this texture refer to second type of kelyphites texture (radial around garnet). The garnet crystal shows medium grain size, highly fracture, color- less to light color with PPL and dark color with XPL expect light to gray color of fracture, because filling with other minerals mostly pyroxene (Figures 6(a) and (b)). Almandine garnet in (Figure 6(a)), 1 - $3 \mathrm{~mm}$ in size, and occurs a phenocryst in plagioclase. The garnet crystals are euhedral to subhedral and they are slightly rounded, mostly garnet highly fractured, produced veins microstructure filling, and intergrowth with pyroxene (opx). The reaction along grained boundaries of garnet is reflected into the presence of kelyphite like rims; kelyphite more investigated in the Scanning Electron Microscope Photomicrograph.

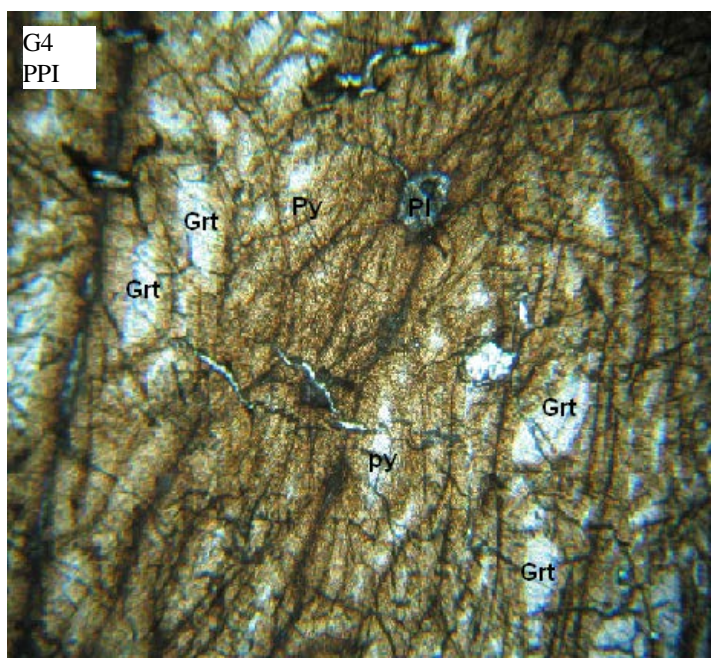

(a)



(b)

Figure 4. Photomicrograph showing: (a) Plagioclase and garnet crystals having a light colored, pyroxene surrounded to garnet (magnification 10×, PPL); (b) Plagioclase gray color first order and, garnet mineral dark color, corona texture shows pyroxene (opx) surrounded to garnet crystal (magnification 10×, XPL, field view $\times 10=1.8 \mathrm{~mm}$, sample No. G4).

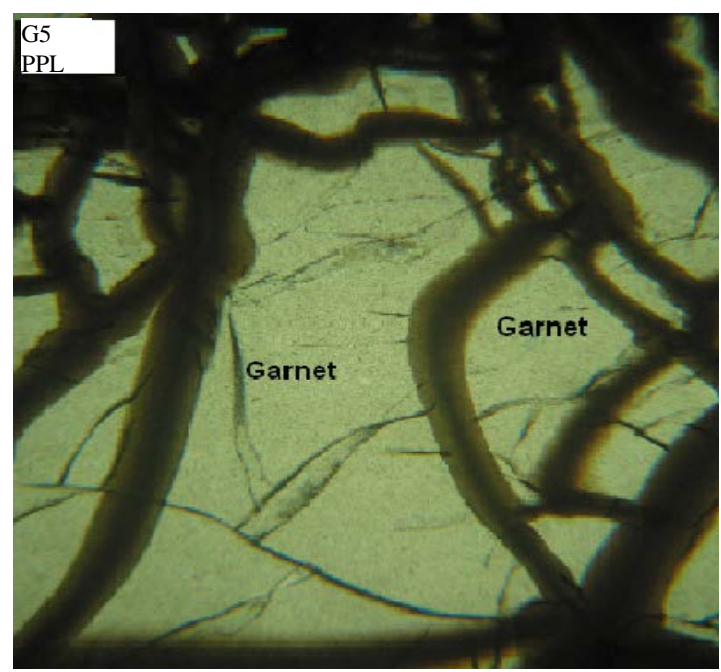

(a)

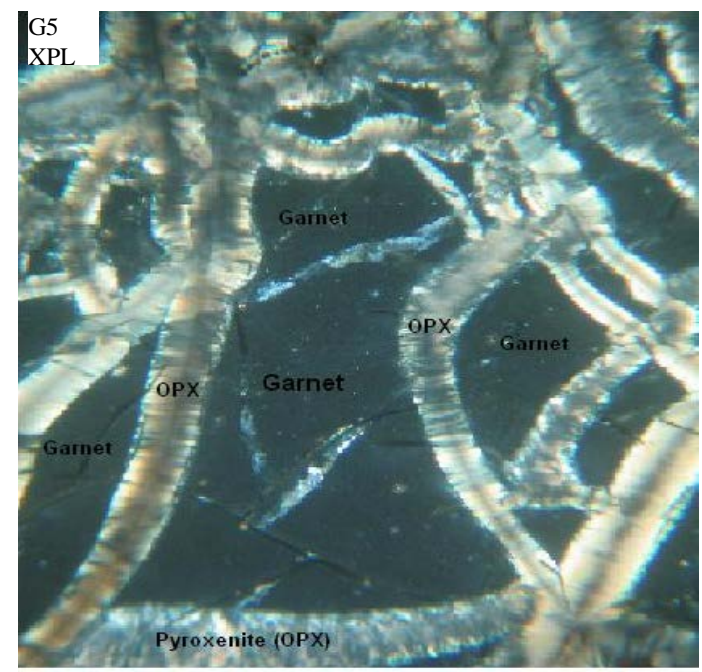

(b)

Figure 5. Photomicrograph showing garnet minerals with highly fractured, and pyroxene (Orthopyroxene) surrounding to garnet mineral form to corona texture, it is refer to second type of kelyphite texture (radial around garnet) (Magnification $4 \times$, PPL and XPL, field view $\times 4=4.4 \mathrm{~mm}$, sample No. G5). 


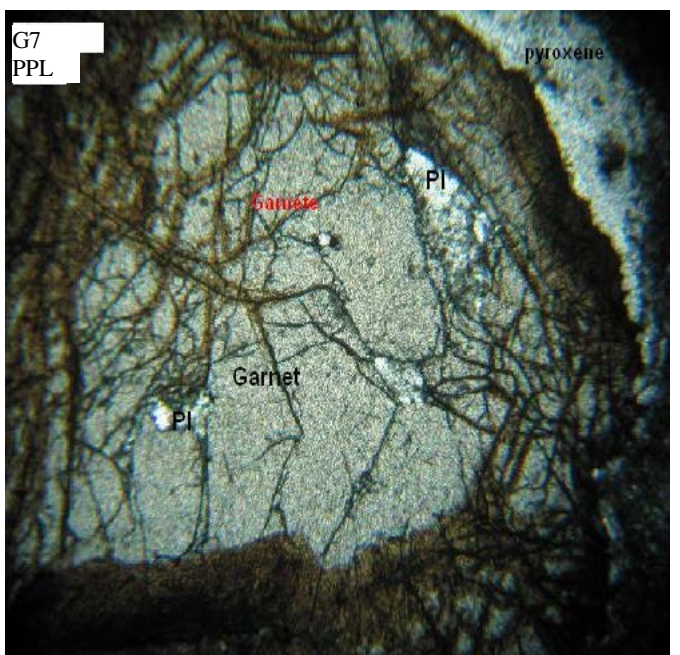

(a)

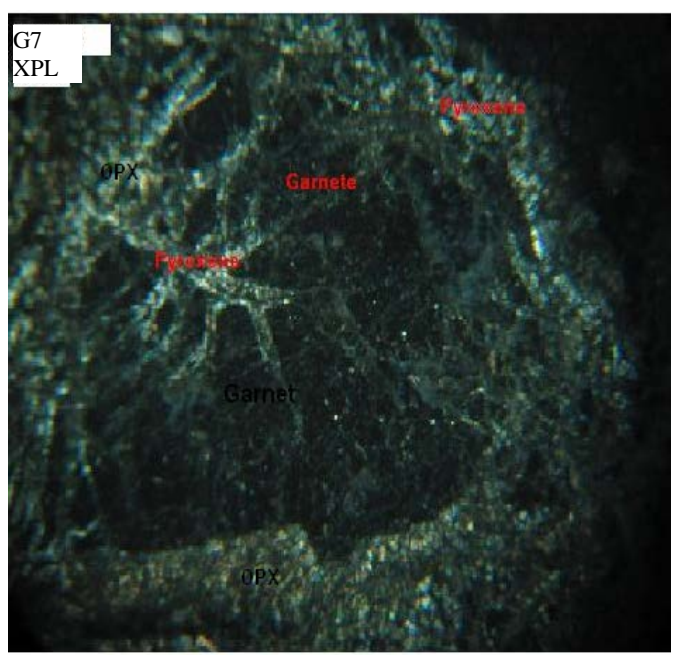

(b)

Figure 6. Photomicrographs showing: (a) Garnet minerals with highly fractured, pyroxene (opx) surrounding to garnet mineral form to corona texture, (Magnification 10 $\times$, PPL, field view $\times 10=1.8 \mathrm{~mm}$ ); (b) Garnet dark color, pyroxene filling the fracture (Magnification 4×, XPL, field view $\times 4=4.4 \mathrm{~mm}$ ), sample No. G7, Ufayhim Formation.

\subsection{Mineralogy}

\subsubsection{X-Ray Diffraction (XRD)}

Minerals identified by XRD include opx (enstatite and donpeacorite), срx (omphacite and Aegerine), Garnet (pyrope, Almandine and majorite), olivine (Forsterite and ringwoodite), magnetite and periclase. The result shows in (Table 2) and (Figure 7). The samples G1, G3, G6 and G8 are composed of pyroxene and olivine minerals, Ensitite $\left(\mathrm{Mg}_{2} \mathrm{Si}_{2} \mathrm{O}_{6}\right)$, omphacite (Ca, $\left.\mathrm{Na}\right)$ (Fe, Mg, $\mathrm{Al}$ ) ( $\mathrm{Si}$, $\mathrm{Al})_{2} \mathrm{O}_{6}$, aegerine $\mathrm{Na}\left(\mathrm{Al}, \mathrm{Fe}^{3+}\right) \mathrm{Si}_{2} \mathrm{O}_{6}$ and forsterite

$\left(\mathrm{Mg}_{2} \mathrm{SiO}_{4}\right)$. Samples G2, G4, G5, G7 and G9 are composed of pyralspite series of garnet minerals include: pyrope $\left(\mathrm{Mg}_{3} \mathrm{Al}_{2} \mathrm{Si}_{3} \mathrm{O}_{12}\right)$, almandine (Fe, $\left.\mathrm{Mn}\right) \mathrm{Al}_{2}\left(\mathrm{SiO}_{4}\right)_{3}$, Majorite $\left(\mathrm{Mg}_{3}(\mathrm{Fe}, \mathrm{Al}, \mathrm{Si})_{2}\left(\mathrm{SiO}_{4}\right)_{3}\right.$, Donpeacorite (Mg, $\mathrm{Mn}) \mathrm{MgSi}_{2} \mathrm{O}_{6}$ and Ringwoodite $\left(\mathrm{Mg}_{2} \mathrm{SiO}_{4}\right)$. All these minerals reflect to form high pressure and temperature for the upper mantle in the earth depth. Almandine garnet occurs in alkaline volcanic rocks. It has may be due to the restricted condition under high-pressure garnet form, and particular geodynamic setting (tensional stress field) rapid ascent of garnet bearing melts $[1,46,47]$. Ringwoodite and majorite minerals are believed to be an abundant mineral in the lower transition zone and uppermost lower mantle of the Earth [48].

\subsubsection{Scanning Electron Microscope (SEM)}

Intact samples were chosen for Scanning Electron Microscopic study to characterize the shape (morphology) of the garnet minerals. The electron micrographs show that the garnet minerals present seen as unhedral crystals in (Figure 8). The photomicrograph shows an important texture and structural features of the garnet represented for kelyphite texture. Petrographical, kelyphite texture is referred to fine grained minerals with fibrous intergrowths of multiple or single phases, such as pyroxene amphibole to form a rim (corona) surrounding garnet [49, 50]. Two types of kelyphite texture observed, first fibrous and second radial structure, the difference between the two types is due to mineralogical composition. The first type of kelyphite surrounded by a thin rim of pyroxenite mostly opx, and separating in the internal to fine grained to form fibrous structure (Figure 9). Preliminary analysis using Electron Back-Scattered Diffraction (EBSD) shows that nodular spinels adjacent fibrous texture; share the same crystallographic orientation (Figure 9(c)). The second type radial structure by pyroxene (opx), shows undulose extinction and low angle tilt boundaries (Figure 5) [49]. In cross-polarized light extinction, angle and interference colors may also changes slightly abruptly.

The two types of kelyphite are radial in a gross scale around garnet. Some features of structural irregularity or internal in coherency occurs, the best visible in transmitted microscope (Figures 5 and 6), and they are highly degree magnification morphology crystals by using Scanning Electron Microscope (Figures 8-11); kelyphite texture shows several lines of internal structure. In cross-polarized light extinction and interference, colors may also change slightly but abruptly (Figure 6). The electron micrograph image, garnet boundary has a curvature, which is often the case, fibers and radial structure, with pyroxene (opx) composition (Figures 5 and 9).

The first type of kelyphite (fibers) consists of a large crystal of opx, which contain several small irregularly shaped patches of clinopyroxene (cpx) (Figure 10). Both opx and cpx contain regularly numerous thin vermicular lamella of pyroxene and spinal (Figure 10(b)), opx do 


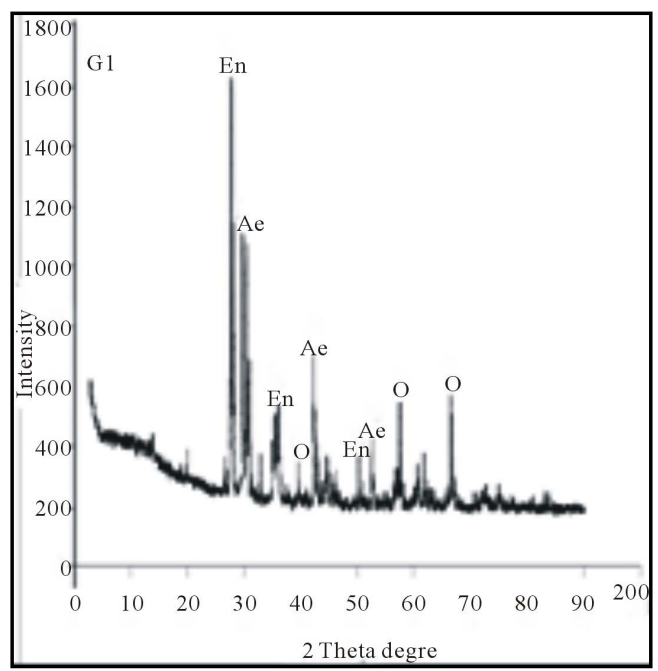

(a)

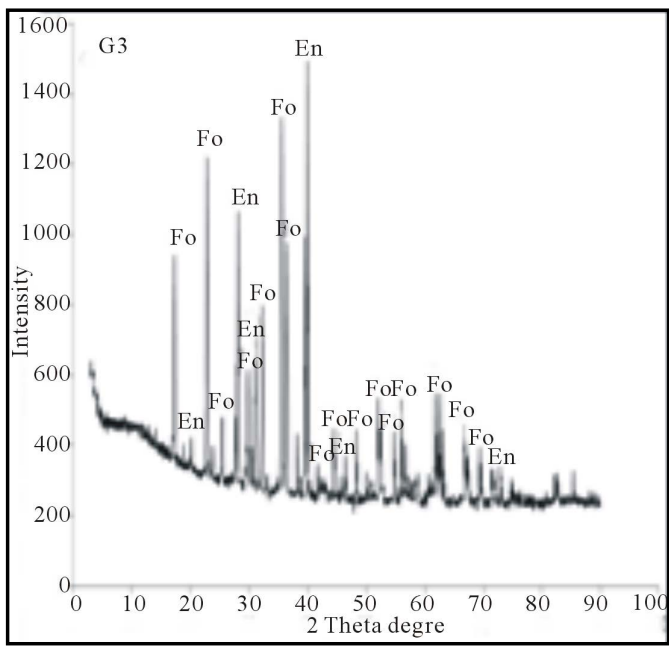

(c)

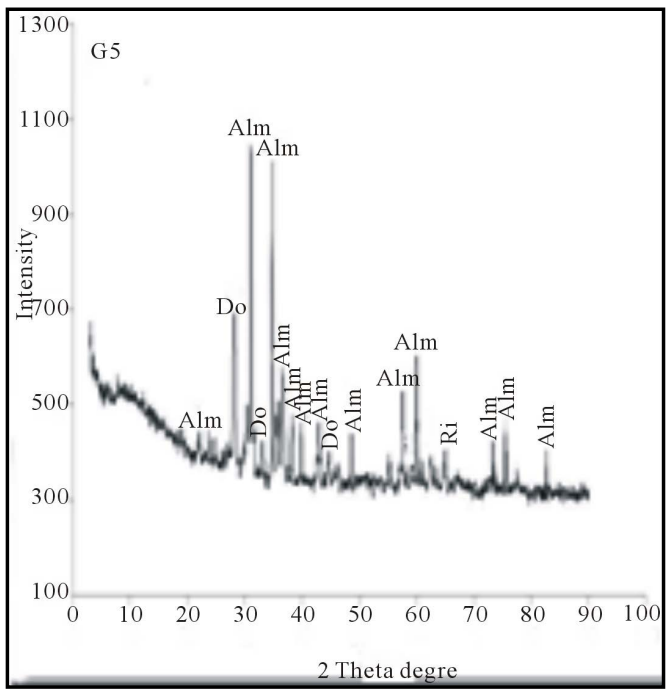

(e)



(b)

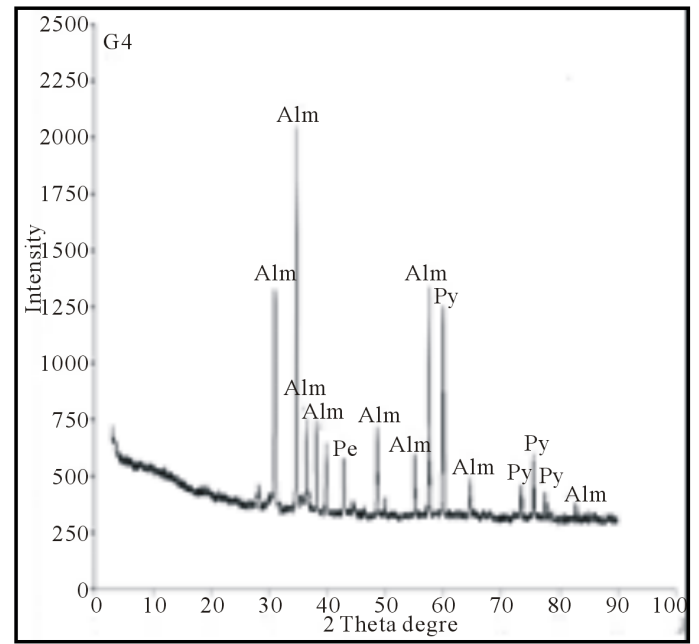

(d)

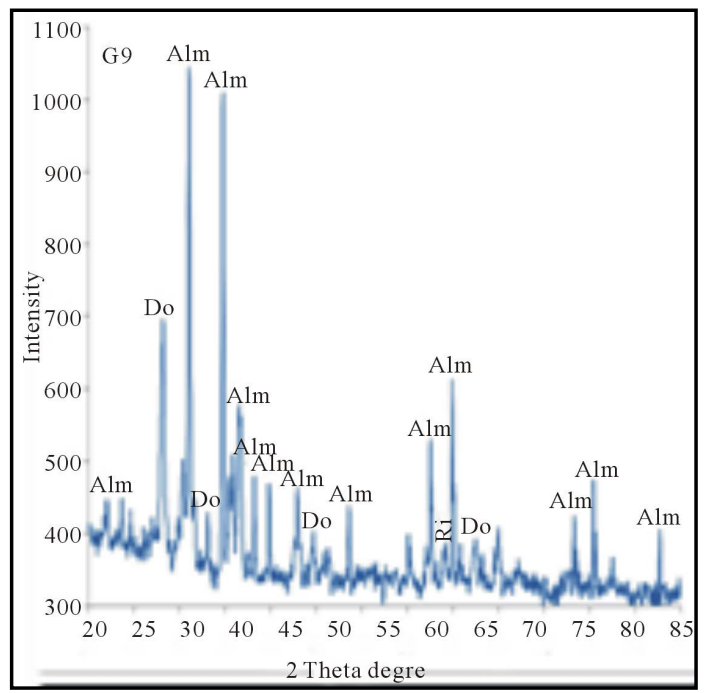

(f)

Figure 7. Mineralogical composition of the samples (G1 - G5) for XRD analysis, (En=Enstatite, Ae=Aegerine, $\mathrm{O}=\mathbf{O m p h a c i t e , ~}$








Figure 8. Electron micrograph images showing unhedral crystals of garnet with highly fracture, and pyroxene surrounding the garnet crystal (Sample No. G4).

Table 2. Qualitative mineralogical composition of samples by (XRD).

\begin{tabular}{|c|c|c|c|c|c|c|c|c|c|c|c|}
\hline S. No. & En & Py & Alm & $\mathbf{O}$ & Ae & Ma & $\mathbf{M j}$ & Fo & $\mathbf{P e}$ & Do & $\mathbf{R i}$ \\
\hline G1 & +++ & & & ++ & ++ & + & & & & & \\
\hline G2 & & & +++ & & & & +++ & & & & \\
\hline G3 & +++ & & & & & & & +++ & & & \\
\hline G4 & & +++ & +++ & & & & & & ++ & & \\
\hline G5 & & & +++ & & & & & & & ++ & + \\
\hline G6 & +++ & & & + & & ++ & & & & & \\
\hline G7 & & +++ & & & & ++ & & & & & \\
\hline G8 & +++ & & & & & & & +++ & & & \\
\hline G9 & & & +++ & & & & & & + & & \\
\hline
\end{tabular}

Note: En = Enstatite, $\mathrm{Py}=$ Pyrope, Alm = Almandine, $\mathrm{O}=$ Omphacite, Ae = Aegerine, $\mathrm{Ma}=$ Magnetite, $\mathrm{Mj}=\mathrm{Majorite}, \mathrm{Pe}=\mathrm{Periclase}, \mathrm{Pe}=\mathrm{Periclase}, \mathrm{Do}=$ Donpeacorite, $\mathrm{Ri}$ = Ringwoodite, Key: Based on Relative XRD high peak Data. Major: +++, Minor: ++, Trace: +

main structure in the polarize light (Figures 5 and 6) but the opx is only confirmed to aid of SEM image (Figure 11). Opx domain has its internal structure of lineation as defined by the opx lamellae, and spinel shows curved lamellae (Figure 11). Spinel lamellas are not necessarily straight but locally may show curved and some time convoluted structure.

The second type of kelyphite (radial), plagioclase is the matrix phase. The plagioclase contains many thin with densely spaced lamellas (Figure 11), or strings of opx lineation resulting in recognizable radial and fibrous structure (Figures 5 and 9). Opx lamellae locally grow to large patches, which contain very fine scaled vermicular intergrowths of spinel. The opx patches tend to get larger spinel occurs only in large opx patches or thick lamellae and not in the plagioclase matrix has been noted [51,52].

\subsection{Minerals Chemistry}

The volcanic xenolith samples are a wide range of silica contents (37.34 - $47.86 \mathrm{wt} \%$ ) and considered by [53] in subalkaline basalt; compared with [29] classified the volcanic rocks in Harrat Ash Shaam as alkaline basalt to basanites. The chemical analysis of the samples (xenolith garnet and pyroxene) at TAH volcanic rocks shown in (Table 3).

\subsubsection{Garnet}

On the basis for the major elements of $\mathrm{MgO}, \mathrm{Fe}_{2} \mathrm{O}_{3}$ and $\mathrm{CaO}$ content, five samples of the garnet were analyses, $\mathrm{MgO}$ (14.21 wt\% - 17.44 wt\%), $\mathrm{Fe}_{2} \mathrm{O}_{3}$ (11.26 wt\% $16.45 \mathrm{wt} \%)$, and $\mathrm{CaO}(4.56 \mathrm{wt} \%$ - $5.45 \mathrm{wt} \%)$. The variation of the chemical composition of the garnet have distinguished to be the garnet type, illustrated in the $\mathrm{Ca}$ 


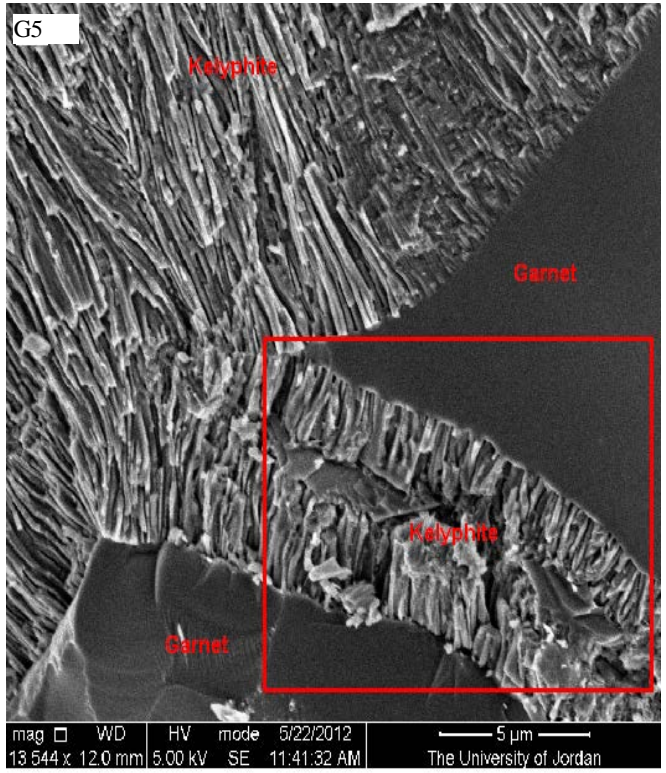

(a)

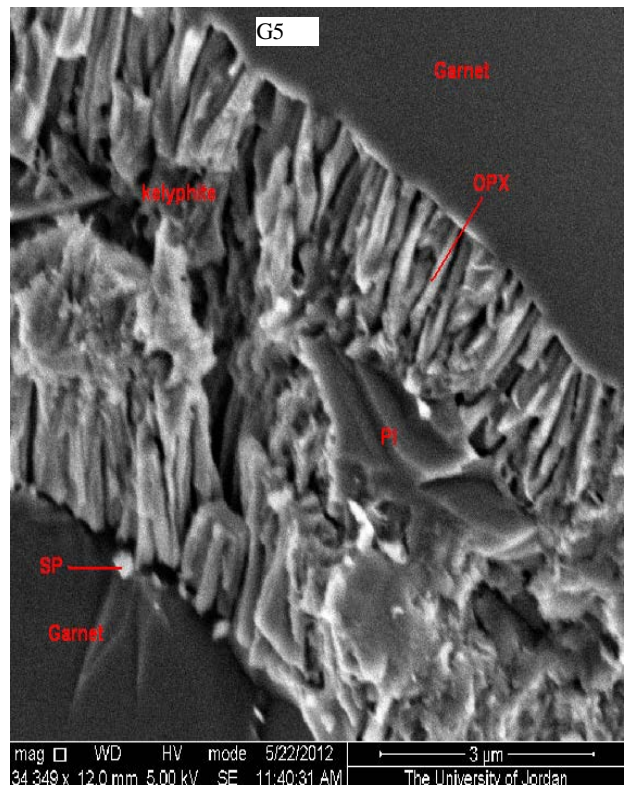

(c)

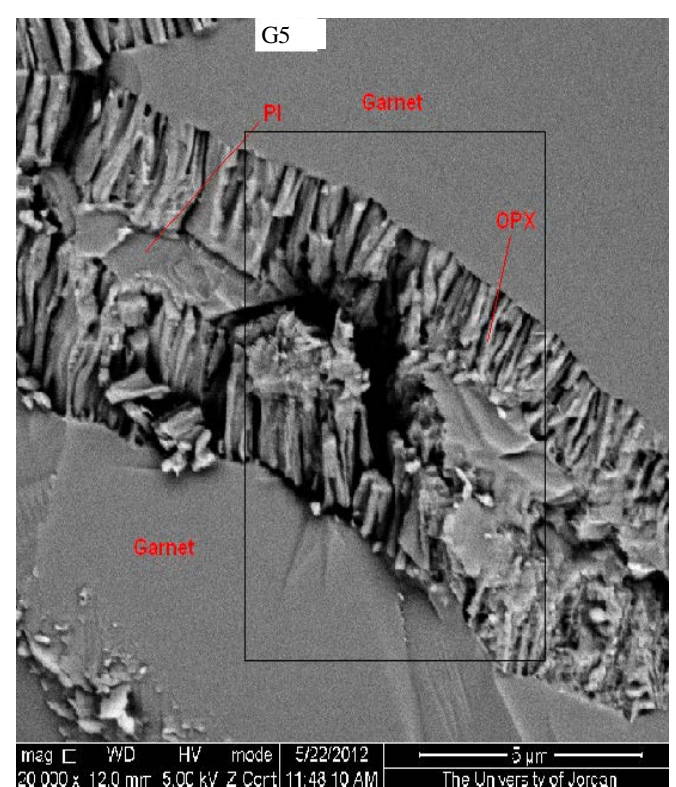

(b)

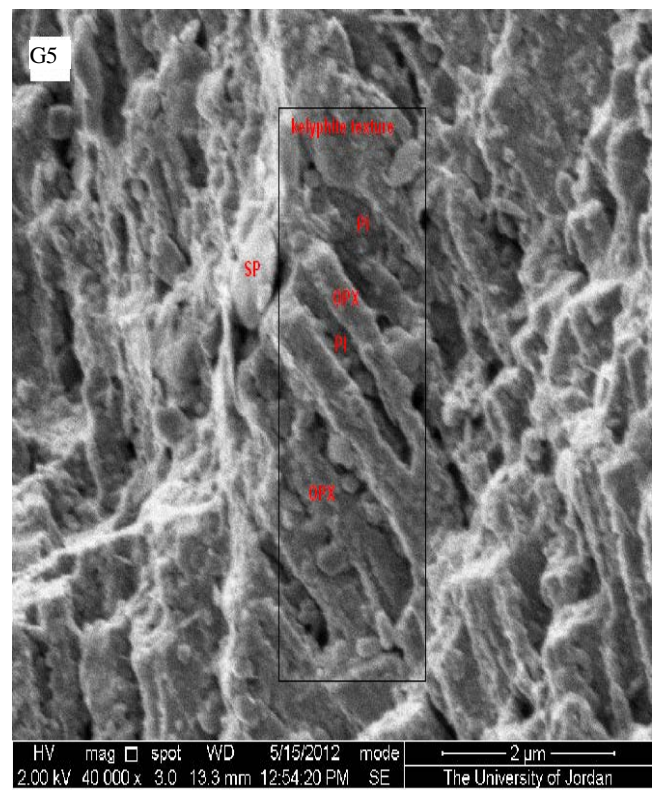

(d)

Figure 9. Electron micrograph images showing kelyphite Type 1, (b) is the enlargement of the framed area in (a), Opx with gray lamellae, and plagioclase dark gray background, (c) and (d) is the enlargement of the framed area in (b) shows opx, pl and nodular spinels adjacent fibrous texture.

(Grossular)-Mg (Pyrope)-Fe (Almandine) diagram (Figure 12). The average composition of garnet (Alm 42.78, Pyro 41.04, Gross 16.18) shown in (Table 3).

The garnet sample in TAH shows the highest percent almandine (G2, $48.00 \mathrm{~mol} \%$ ) and pyrope (G4, 45.16 mol\%) component, referred to the $\mathrm{Fe}_{2} \mathrm{O}_{3}$ and $\mathrm{MgO}$ content values, and it has revealed particularly at high and low almandine and pyrope content, compared to [54] measured $\mathrm{Fe}_{2} \mathrm{O}_{3}$ content of garnet by [55] in Hungarian volcanic rocks, whereas the sample lower $\mathrm{Fe}_{2} \mathrm{O}_{3}$ content low almandine component [1]. The garnet study shows $\mathrm{Fe}$ - Mg abundance, compared to Ca grossular content. According [1] volcanic rocks have relatively high grossular (Gross $>6 \mathrm{~mol} \%$ ) and the garnet rich in Ca (Gross $10-18$ mol\%), the garnet study in TAH have grossular within the range (14.61 mol\% - $17 \mathrm{~mol} \%$ ).

The interrelationship of $\mathrm{Na}_{2} \mathrm{O}, \mathrm{TiO}_{2}$ and $\mathrm{P}_{2} \mathrm{O}_{5}$ in garnet have been explored by many authors [44,56-60] all attempt in these researches were to identify the substitution of elements $\mathrm{Na}, \mathrm{Ti}$ and $\mathrm{P}$ in the upper mantle garnets. 


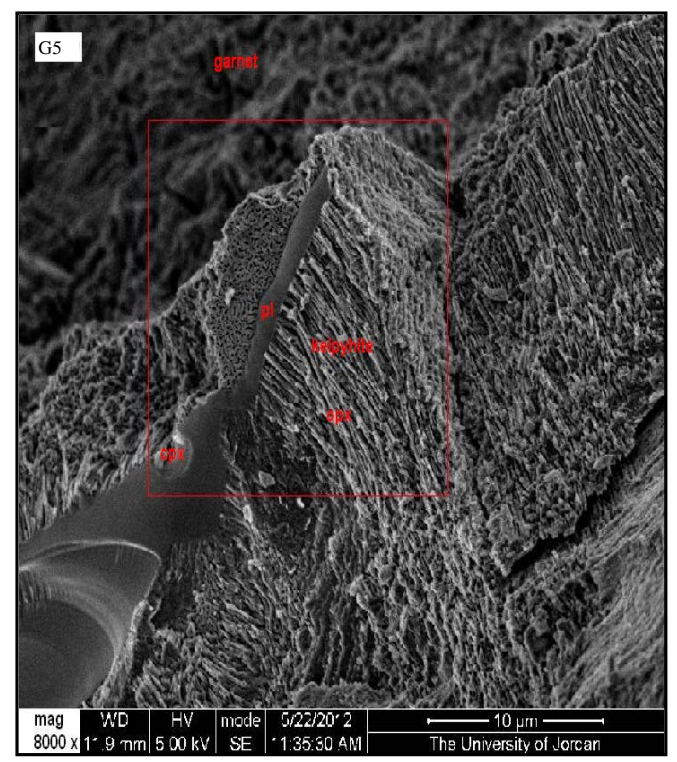

(a)

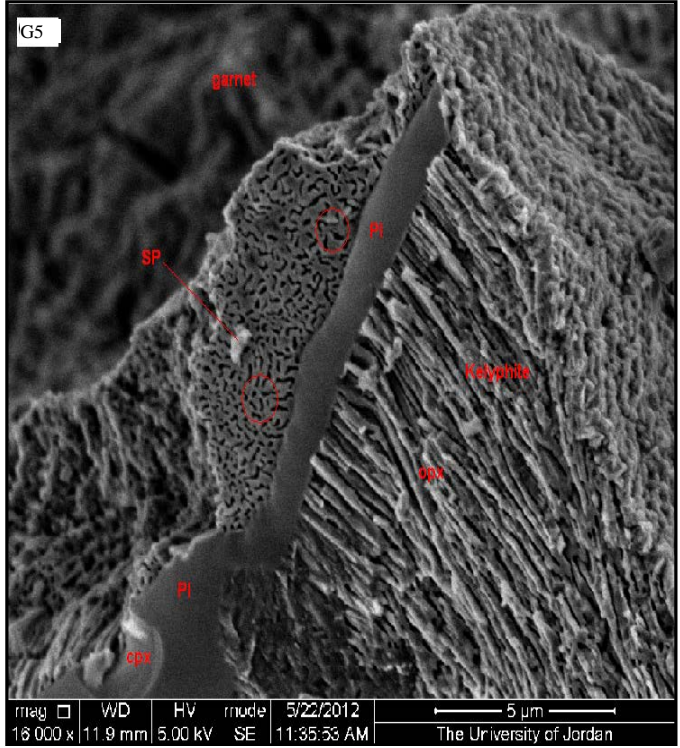

(b)

Figure 10. Electron micrograph images showing kelyphite Type 1, (b) is the enlargement of the framed area in (a), showing vermicular intergrowths of $\mathrm{opx}, \mathrm{cpx}$ and sp, light gray patches cpx, dark gray opx, dark gray strings are spinel (sp), circles mark convoluted spinel lamellae, spinel nodules shows within vermiculate.

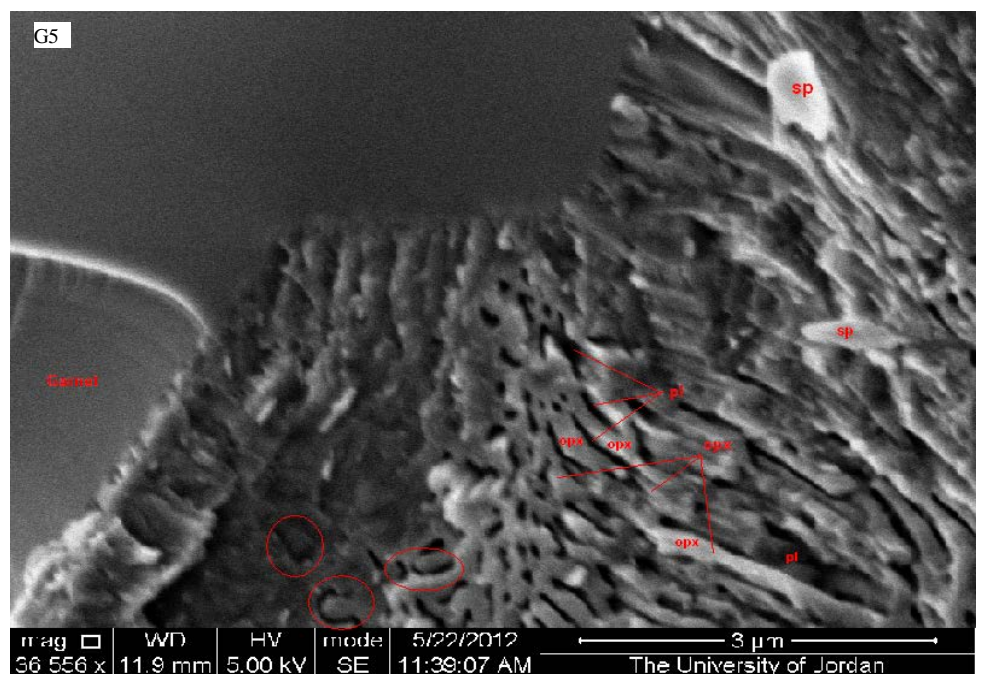

Figure 11. Electron micrograph image showing kelyphite Type 2, white gray lamellae, opx, dark gray background, pl, showing vermicular intergrowths of opx, cpx and sp, light gray lamella opx, dark lamella pl, dark gray strings are spinel, circles mark convoluted spinel lamellae, spinel nodules shows within vermiculate.

The $\mathrm{Na}_{2} \mathrm{O}$ concentrations (0.053 - 0.344 wt\%) in $\mathrm{TAH}$ garnet are smellier to the garnet for peridotite and eclogite garnet [43,57-59,61]. The $\mathrm{TiO}_{2}(0.48-0.97 \mathrm{wt} \%)$ in the garnet TAH have agreement for the range recorded in Udachnaya (Russia) eclogit garnet [15] and high percent compared with Koidu garnet [44]. The $\mathrm{P}_{2} \mathrm{O}_{5}$ in the TAH garnet range (0.023 - $0.039 \mathrm{wt} \%$ ), phosphorous rich in sample G4 and G5 (0.039 wt\%, $0.038 \mathrm{wt} \%)$, these indication for CIPW norm calculation that are apatite normative.

The correlation between $w t \% \mathrm{Na}_{2} \mathrm{O}$ and $\mathrm{TiO}_{2}$ of $\mathrm{TAH}$ garnet is positive, with low wt\% MgO (Figure 13).
Strong positive correlation in a plot of weight percent $\mathrm{Na}_{2} \mathrm{O}$ versus wt\% $\left(\mathrm{TiO}_{2}+\mathrm{P}_{2} \mathrm{O}_{5}\right)$ in (Figure 13(c)), this indication that $\mathrm{Na}$ in garnet may indeed to be explained by coupled substitution with $\mathrm{Ti}$ and $\mathrm{P}$ in garnet $[44,58]$. According [44], the abundance of $\mathrm{Na}, \mathrm{Ti}$ and $\mathrm{P}$ in mantle garnet confirms that substitution of these elements in garnet structure at high pressure, and that garnet storage for $\mathrm{Na}$, Ti and $\mathrm{P}$ in upper mantle rocks.

The CIPW norm calculation of garnet TAH show plagioclase, corundum, Hypersthen, and hematite, and low percent of quartz (Table 3). 
Table 3. Chemical composition of the samples wt \%, calculation formula mol\% components and wt \% normative.

\begin{tabular}{|c|c|c|c|c|c|c|c|c|c|}
\hline S.No. & G1 & G2 & G3 & G4 & G5 & G6 & G7 & G8 & G9 \\
\hline $\mathrm{SiO}_{2} \mathrm{wt} \%$ & 47.86 & 37.47 & 41.29 & 37.34 & 37.91 & 48.21 & 38.93 & 43.82 & 39.35 \\
\hline $\mathrm{TiO}_{2}$ & 0.649 & 0.69 & 0.142 & 0.486 & 0.512 & 0.733 & 0.975 & 0.145 & 0.65 \\
\hline $\mathrm{Al}_{2} \mathrm{O}_{3}$ & 8.761 & 22.56 & 4.113 & 23.10 & 24.72 & 8.12 & 24.55 & 3.24 & 24.74 \\
\hline $\mathrm{Fe}_{2} \mathrm{O}_{3}$ & 8.039 & 16.45 & 8.828 & 12.80 & 11.26 & 8.79 & 15.63 & 8.73 & 11.76 \\
\hline $\mathrm{MnO}$ & 0.109 & 0.24 & 0.113 & 0.221 & 0.27 & 0.146 & 0.275 & 0.156 & 0.25 \\
\hline $\mathrm{MgO}$ & 19.978 & 15.01 & 41.13 & 17.45 & 15.14 & 21.56 & 14.21 & 40.98 & 15.86 \\
\hline $\mathrm{CaO}$ & 10.945 & 5.631 & 2.218 & 4.559 & 5.118 & 9.85 & 4.64 & 2.35 & 5.12 \\
\hline $\mathrm{Na}_{2} \mathrm{O}$ & 1.218 & 0.344 & 0.465 & 0.305 & 0.053 & 0.25 & 0.15 & 0.31 & 0.062 \\
\hline $\mathrm{K}_{2} \mathrm{O}$ & 0.019 & 0.034 & 0.044 & 0.084 & 0.093 & 0.03 & 0.108 & 0.045 & 0.075 \\
\hline $\mathrm{P}_{2} \mathrm{O}_{5}$ & 0.035 & 0.037 & 0.043 & 0.039 & 0.038 & 0.012 & 0.023 & 0.063 & 0.023 \\
\hline L.O.I & 2.500 & 1.35 & 2.199 & 3.000 & 3.75 & 0.32 & 0.35 & 0.21 & 1.84 \\
\hline Sum & 100.12 & 99.82 & 100.57 & 99.37 & 98.87 & 98.02 & 100.84 & 100.04 & 99.73 \\
\hline \multicolumn{10}{|c|}{ Garnet composition: grassular, pyrope and almandine (mole percent) } \\
\hline Grassular & & $16.75 \%$ & & $14.62 \%$ & $17.53 \%$ & & $14.65 \%$ & & $17.36 \%$ \\
\hline Pyrope & & $35.25 \%$ & & $45.16 \%$ & $44.66 \%$ & & $36.56 \%$ & & $43.55 \%$ \\
\hline Almandine & & $48.00 \%$ & & $40.22 \%$ & $37.81 \%$ & & $48.79 \%$ & & $39.10 \%$ \\
\hline & \multicolumn{9}{|c|}{ Pyroxene composition : wollastanite, enstatite and ferrosilite, (mole percent) } \\
\hline Wollastanite & $30.55 \%$ & & $4.83 \%$ & & & $25.23 \%$ & & $7.00 \%$ & \\
\hline Enstatite & $47.08 \%$ & & $75.92 \%$ & & & $50.67 \%$ & & $77.25 \%$ & \\
\hline Ferrosilite & $22.37 \%$ & & $19.25 \%$ & & & $24.10 \%$ & & $15.76 \%$ & \\
\hline CIPW-Norm & \multicolumn{9}{|c|}{ Weight \% Norm } \\
\hline Qz & & 1.52 & & 3.96 & 3.96 & & 9.43 & & 4.24 \\
\hline $\mathrm{Pl}$ & 29.41 & 32.45 & 13.19 & 26.64 & 26.95 & 23.56 & 24.18 & 9.95 & 26.32 \\
\hline Or & 0.12 & 0.24 & 0.03 & 0.59 & 0.53 & 0.18 & 0.65 & 0.30 & 0.42 \\
\hline Co & & 10.31 & & 12.96 & 16.02 & & 14.67 & & 15.62 \\
\hline Di & 27.09 & & 1.53 & & & 20.23 & & 3.07 & \\
\hline Hy & 22.03 & 36.84 & 10.69 & 43.93 & 39.55 & 43.30 & 35.22 & 22.91 & 40.35 \\
\hline Ol & 11.47 & & 64.97 & 1.49 & & 1.52 & & 54.60 & \\
\hline $\mathrm{Ru}$ & & 0.71 & & 0.25 & 0.49 & & 0.66 & & 0.37 \\
\hline IL & 0.26 & 0.06 & 0.27 & 0.51 & 0.12 & & 0.60 & 0.28 & 0.56 \\
\hline $\mathrm{He}$ & 8.23 & 17.37 & 8.96 & 13.56 & 11.85 & 8.98 & 14.56 & 8.68 & 12.01 \\
\hline Ap & 0.09 & 0.09 & 0.09 & 0.09 & 0.09 & 0.02 & 0.05 & 0.40 & 0.05 \\
\hline $\mathrm{Zr}$ & 0.03 & 0.03 & 0.04 & 0.04 & 0,04 & 0.04 & 0.04 & & \\
\hline Sph & 1.31 & & & & & 1.84 & & & \\
\hline
\end{tabular}

Qz: Quartz, Pl: Plagioclase, Or: Orthoclase, Di: Diopside, Hy: Hypersthen, Ol: Olivine, Il: Limonite, He: Hematite, Ap: apatite, Zr: Zirecon, Sph: Sphene, Co: Corundum.

\subsubsection{Pyroxene}

The chemical analyses of the pyroxene samples, show the variation composition of $\mathrm{CaO}, \mathrm{MgO}$ and $\mathrm{F}_{2} \mathrm{O}_{3}$, and a wide range of $\mathrm{CaO}$, (2.21 - $10.94 \mathrm{wt} \%)$ and $\mathrm{MgO}$ (19.97
- 41.12 wt\%), but $\mathrm{Fe}_{2} \mathrm{O}_{3}$ (8.04 - 8.82 wt\%) has low range. These don't differ significantly of the average composition of pyroxene (Wo 16.90, Fs 20.37, En 62.73) from the primary pyroxenes $\mathrm{Ca}, \mathrm{Mg}$, Fe component, (Figure 


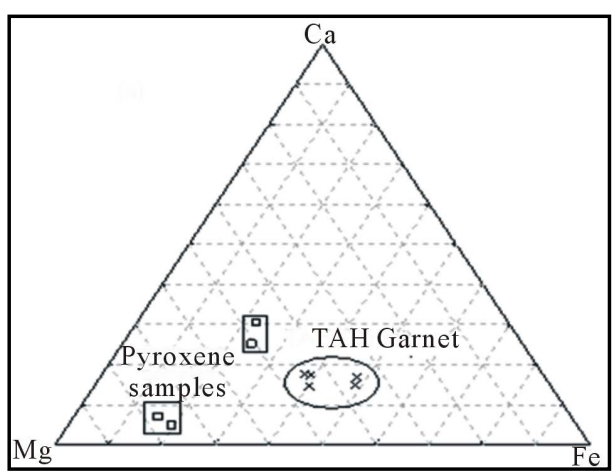

(a)

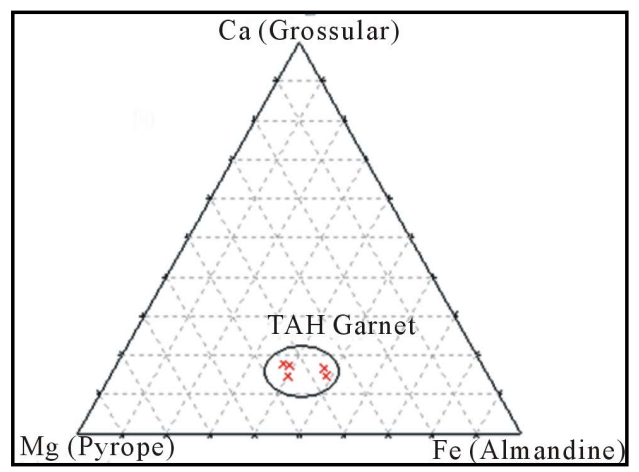

(b)

Figure 12. (a) Variation of chemical composition of the garnet and pyroxene in the Ca-Mg-Fe diagram; (b) Average composition of the garnet type from TAH, plotted as mole percent. Grossular-pyrope-almandine, plotted are the fields of high and low MgO TAH garnet.

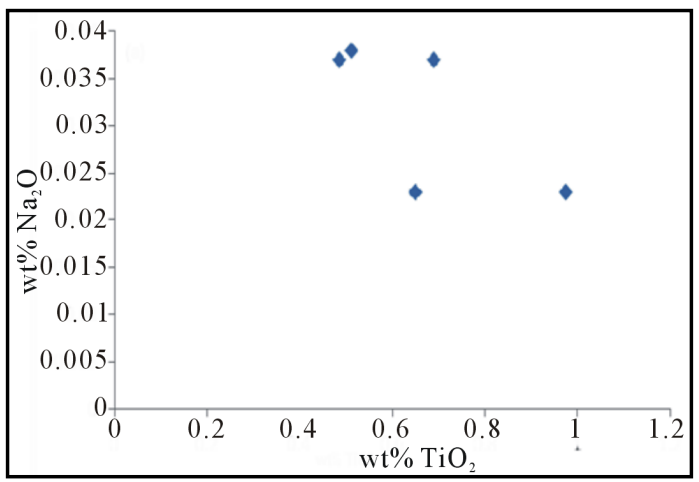

(a)

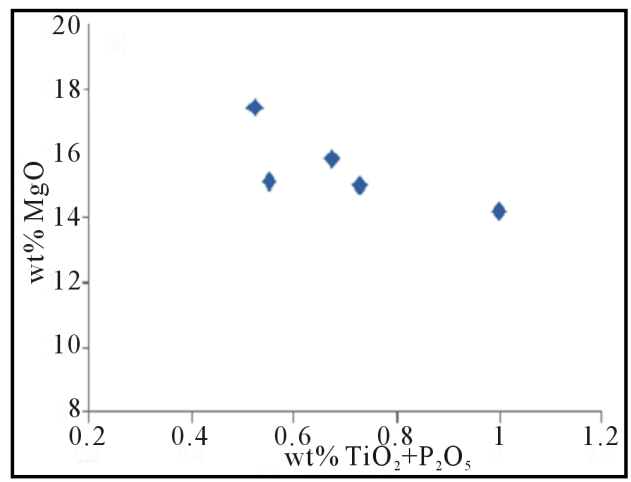

(b)

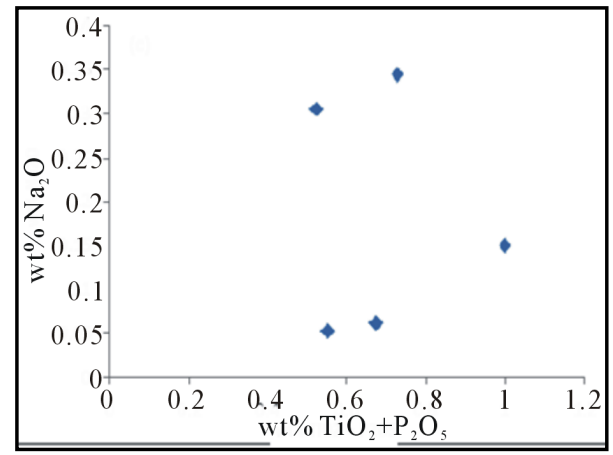

(c)

Figure 13. (a) Plots of wt\% $\left(\mathrm{TiO}_{2}\right.$ versus $\left.\mathrm{Na}_{2} \mathrm{O}\right)$; (b) wt $\%\left(\mathrm{TiO}_{2}+\mathrm{P}_{2} \mathrm{O}_{5}\right)$ versus $\mathrm{MgO}$; (c) wt $\%\left(\mathrm{TiO}_{2}+\mathrm{P}_{2} \mathrm{O}_{5}\right)$ versus $\mathrm{Na}_{2} \mathrm{O}$ for TAH garnet samples.

14). The CIPW norm calculation indicates that diopside $\left(\mathrm{CaMgSi}_{2} \mathrm{O}_{6}\right)$ and hypersthenes $\left(\mathrm{MgFeSi}_{2} \mathrm{O}_{6}\right)$ normative identifies in pyroxene, this due to the partial melting of pyroxene to distinctly diopside [44].

\subsubsection{Plagioclase}

Plagioclase is the most common mineral in the garnet bearing volcanic rocks of the TAH area, occurring as a phenocryst intergrowth with garnet (Figures 4 and 6). Plagioclase inclusion in garnet samples has distinctive lamellae for kelyphite (Figures 10 and 11). Chemically, CIPW norm calculation of plagioclase, identify to anorthite (29.30 wt\% norm), and albite (3.0 wt\% norm), more content calcic than sodic plagioclase, and low amount of orthoclase.

\section{Origin of Basaltic Garnet Xenoliths}

The basaltic xenoliths transported to the surface in alkali to subalkali basalt, are documents into the information 


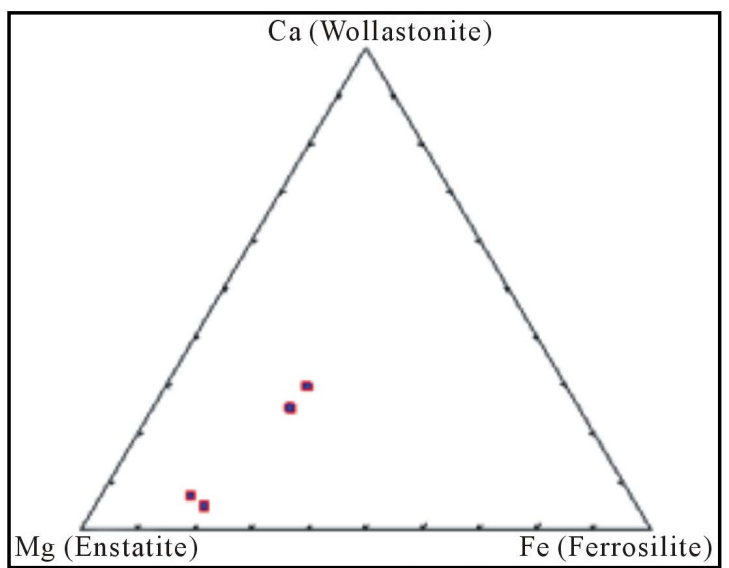

Figure 14. Pyroxene (xenocryst) compositions from TAH, asmole percent Wollastonite-Enstatite-Ferrosilite.

composition and evolution of the lithospheric mantle. Mafic to ultramafic composition xenoliths from continental areas are reported by [25], and he suggest that the mantle has complicated and the xenoliths have depleted mantle. The xenoliths samples examined in this work, investigated a primary assemblage ol $+\mathrm{pl}+\mathrm{opx}^{+} \mathrm{cpx}^{+}$ Grt \pm sp, for model and SEM images. Five samples contain garnet surrounding by opx and plagioclase filling the cracks inters garnet crystal. Xenoliths similar in composition have been reported in Jordan, Saudi Arabia and Syria by [23,62-66].

The previous studies of Jordan xenoliths are documented by many authors, e.g., [67], reported the temperatures $\left(900^{\circ} \mathrm{C}-1030^{\circ} \mathrm{C}\right)$, and pressure $(12-18 \mathrm{kbar})$, within $(37-60 \mathrm{~km})$ depth for peridotites and pyroxenite. [67-69] estimated the lower end of the crust-mantle boundary (35 - $37 \mathrm{~km})$. [63] Studied the xenoliths in Saudi Arabia, and reported the same temperatures $\left(900^{\circ} \mathrm{C}\right.$ $\left.-980^{\circ} \mathrm{C}\right)$ and pressure $(13-19 \mathrm{kbar})$ for peridotites, and temperatures $\left(900^{\circ} \mathrm{C}-1070^{\circ} \mathrm{C}\right)$ and pressure $(13.8-16.5$ kbar) for pyroxenite. [26] studied the xenoliths in the volcanic rocks northeast Jordan and conclude the temperature range from $\left(970^{\circ} \mathrm{C}-1090^{\circ} \mathrm{C}\right)$ and pressure at 19 - $27 \mathrm{kbar}$ and depth around to $65 \mathrm{~km}$. [14] studied the xenoliths in Jabal al-Harida by using Herzberg method and reported temperature range $\left(960^{\circ} \mathrm{C}-1040^{\circ} \mathrm{C}\right)$, and pressure $11-13 \mathrm{~kb}$, and depth of the origin $43 \mathrm{~km}$. [70] Reported thermometer for pyroxene and peridotite, temperature range $\left(1022^{\circ} \mathrm{C}-1083^{\circ} \mathrm{C}\right)$, and pressure range $(5$ - $10 \mathrm{kbar}$ ). I support that, all authors explained the origin of xenoliths as shallow lithosphere mantle in Jordan.

\section{Conclusions}

The garnet mineral xenolith occurs in and is associated with the Miocene volcanic field at basalt plateau north east Jordan at TAH. The results of this study can be gleaned and concluded as follows:
1) The primary minerals assemblages for modal component xenoliths are ol $+\mathrm{pl}+\mathrm{opx}+\mathrm{cpx} \pm \mathrm{sp}$.

2) The petrography shows that the garnet mineral is dark brown to dark red in color with fresh fracture in hand spacement. In thin section, garnet crystal unhedral to subhedral, dark color in XPL, corona texture present, pyroxene surrounding garnet crystal.

3) The SEM photomicrograph shows the crystal habit of the garnet, highly fractured and surrounded by kelyphite texture. Two types of kelyphite texture are distinguished, fibrous and radial. Both opx and cpx are containing a regular numerous vermicular lamella of pyroxene and spinel.

4) The mineral chemistry of the TAH garnet is rich in almandine than pyrope and grossular, these components refer to the $\mathrm{Mg}$, Fe and $\mathrm{Ca}$ content. Pyroxene composition shows highly Ensitite content than Wollastonite and Ferrosilite.

5) Many authors explain the origin of the xenoliths, conclude to shallow lithosphere mantle.

\section{Acknowledgments}

The author of this research would like to express his sincere thanks to Ali Abed-al Jawad for performing the XRF and XRD analysis and Eng. Raya Al-Amoush for her help in the SEM analysis at $\mathrm{Al}$ al-Bayt University. The author is also grateful to the Geologist Yousef Abu Salha for SEM analysis at the University of Jordan, and for Mrs. Ameenah Al-Kourdi for her help in thin sections preparation at the University of Jordan. The author also thanks the Geologist Asmaa Al-Qurneh from the Petrology and Petrography unit in the Natural Resources Authority for her help in photographing thin section. The text has benefited from the comments of anonymous reviewers to whom the author are highly indebted and grateful.

\section{REFERENCES}

[1] S. Z. Harangi, H. Downes, L. Kosa, C. S. Szabo, M. Thirlwall, P. Mason and D. Mattey, "Almandine Garnet in Calc-Alkaline Volcanic Rocks of the Northern Pannonian Basin (Eastern-Central Erope): Geochemistry, Petrogenesis and Geodynamic Implications,” Journal of Petrology, Vol. 42, No. 10, 2001, pp. 1813-1843. http://dx.doi.org/10.1093/petrology/42.10.1813

[2] T. H. Green and A. E. Ringwood, "Origin of the Garnet Phenocrysts in Calc-Alkaline Rocks,” Mineralogy and Petrology, Vol. 18, No. 2, 1968, pp. 163-174. http://dx.doi.org/10.1007/BF00371807

[3] B. J. Henson and D. H. Green, "Experimental Study of the Stability of Cordierite and Garnet in Pelitic Composition at High Pressures and Temperatures," Mineralogy and Petrology, Vol. 38, No. 2, 1973, pp. 151-166.

http://dx.doi.org/10.1007/BF00373879 
[4] T. H. Green, "Experimental Generation of Cordierite or Garnet Bearing Granitic Liquids from a Pelitic Composition," Geology, Vol. 4, No. 2, 1976, pp. 85-88. http://dx.doi.org/10.1130/0091-7613(1976)4<85:EGOCG $\underline{\mathrm{G}}>2.0 . \mathrm{CO} ; 2$

[5] T. H. Green, "Garnet in Silicic Liquids and Its Possible Use as: A P-T Indicator,” Mineralogy and Petrology, Vol. 65, No. 1, 1977, pp. 59-67. http://dx.doi.org/10.1007/BF00373571

[6] T. H. Green, "Experimental Phase Equilibrium Studies of Garnet-Bearing I-Type Volcanic and High-Level Intrusive from Northland, New Zealand,” Earth Sciences, Vol. 83, 1992, pp. 429-438.

[7] J. D. Clemens and V. J. Wall, "Crystallization and Origin of Some Peraluminous (S-Type) Granitic Magmas,” Canadian Mineralogist, Vol. 19, 1981, pp. 111-132.

[8] W. K. Conrad, I. A. Nicholls and V. J. Wall, "WaterSaturated and under Saturated Melting of Metaluminous and Peraluminous Crystal Composition at $10 \mathrm{~kb}$ : Evidence for the Origin of Silicic Magmas in the Taupo Volcanic Zone, New Zealand and Other Occurrences,” Journal of Petrology, Vol. 29, No. 4, 1988, pp. 765-803. http://dx.doi.org/10.1093/petrology/29.4.765

[9] J. G. Fitton, "The Genetic Significance of Almandine-Pyrope Phenocrysts in the Calc-Alkaline Borrowdale Volcanic Group, Northern England,” Mineralogy and Petrology, Vol. 36, No. 3, 1972, pp. 231-248. http://dx.doi.org/10.1007/BF00371434

[10] J. S. Gilbert and N. W. Rogers, "The Significance of Garnet in the Permo-Carboniferous Volcanic Rocks of the Pyrenees," Journal of the Geological Society, Vol. 146, No. 3, 1989, pp. 477-490. http://dx.doi.org/10.1144/gsigs.146.3.0477

[11] T. F. Agnes and E. H. Stephen, "Petrology and Mineral Compositions of Ecllllogites from the Koidu Kimbrlite Complex, Sierra Leone," Journal of Geophysical Research, Vol. 100, 1995, pp. 451-473.

[12] D. L. Anderson, "A Global Geochemical Model for the Evolution of the Mantle,” In: R. I. O’Connell and W. S. Fyfe, Eds., Evolution of the Earth, AGU, Washington DC, 1981, pp. 6-18.

[13] D. L. Anderson, "Kimberlite and the Evolution of the Mantle, in Kimberlites," Kimberlites and Related Rocks, Dev. Petro, Vol. 1, 1984, pp. 395-403.

[14] A. Al-Malabeh, "Cryptic Mantle Metasomatism: Evidences from Spinel l Herzolite Xenoliths/Al-Harida Volcno in Harrat Al-Shaam, Jordan,” American Journal of Applied Sciences, Vol. 6, No. 12, 2009, pp. 2085-2092. http://dx.doi.org/10.3844/ajassp.2009.2085.2092

[15] N. V. Sobolev, "Deep-Seated Inclusion in Kimberlites and the Problem of the Composition of the Upper Mantle," Edwards, Ann Arbor, 1977, p. 279. http://dx.doi.org/10.1029/SP011

[16] J. B. Dawson, “Kimberlites and Their Xenoliths,” Springer Verlag, New York, 1980, p. 252. http://dx.doi.org/10.1007/978-3-642-67742-7

[17] D. C. Smith, "Eclogites and Eclogite Facies Rocks,” Elsevier Science, New York, 1988, p. 524.
[18] R. O. Moore and J. J. Gurney, "Pyroxene Solid Solution in Garnets Included in Diamond,” Nature, Vol. 318, 1985, pp. 553-555. http://dx.doi.org/10.1038/318553a0

[19] A. L. Jaques, S. F. Haggerty, H. Lucas and L. Boxer, "Mineralogy and Petrology of the Argyle (AKI) Lamproite Pipe, Western Australia, in Kimberlites and Related Rocks,” The Geological Society, Vol. 14, 1989, pp. 153-169.

[20] K. M. Ibrahim and R. Mahmoud, "Geological Map of Wadi Gharandal, Sheet No. 3050 II, Scale 1:50,000,” Natural Resources Authority, Geological Map Division, Jordan, 1988.

[21] F. Bender, “Geology of Jordan,” Gebrüder Bornträger Verlag, Berlin, 1974, p. 196.

[22] A. Hafez, "Upper Mantle Derived Ultramafic Xenoliths from Jebel Aritain, Hashemite Kingdom of Jordan,” Ann. Geo. Surv. Egypt, Vol. 15, 1986, pp. 129-136.

[23] S. Nasir and H. Al-Fuqha, "Spinel-Iherzolite Xenoliths from the Aritain Volcano, NE-Jordan," Mineralogy and Petrology, Vol. 38, No. 2, 1988, pp. 127-137. http://dx.doi.org/10.1007/BF01164317

[24] A. Al-Malabeh, "Discovery of Ultrmafic Xenolith Rich Layer in the Tephra Succession of Jabal Aritain-South Jordan,” R. J. Mineral Deposits, Vol. 12, 2004, pp. 23-35.

[25] J. E. Shaw, J. A. Baker, A. J. Kent, K. M. Ibrahim and M. A. Menzies, "The Geochemistry of the Arabian Lithospheric Mantle-A Source for Interaplate Volcanism," Journal of Petrology, Vol. 48, No. 8, 2007, pp. 14951512. http://dx.doi.org/10.1093/petrology/egm027

[26] H. Al-Fugha and M. Al-Amaireh, "Petrology and Origin of Ultramafic Xenoliths from North Eastern Jordan Volcanoes," American Journal of Applied Sciences, Vol. 4, No. 7, 2007, pp. 491-495.

[27] I. Bany Yaseen, M. Alabouny and A. Tate, "Geology and Geochemistry Study Minerals at Tal Hamlan/As Safawi," Internal Report, Natural Resources Authority (NRA), Amman, 2009.

[28] K. Tarawneh, "Mineralogy and Petrology of New Occurrences Deposits of the Zeolitic Tuff in Northeast Jordan," Mineralogy and Petrology, Vol. 47, 2004, pp. 171-175.

[29] J. E. Shaw, J. A. Baker, M. A. Menzies, M. F. Thirlwall and K. M. Ibrahim, "Petrogenesis of the Largest Intraplate Volcanic Field on the Arabian Plat (Jordan): A Mixed Lithosphere-Asthenosphere Source Activated by Lithospheric Extension,” Journal of Petrology, Vol. 44, No. 9, 2003, pp. 1657-1679.

http://dx.doi.org/10.1093/petrology/egg052

[30] F. Barberi, G. Capaldi, P. Gasperini, G. Marinelli, R. Santacroce, R. Scandone, M. Treuil and J. Varet, "Recent Basaltic Volcanism of Jordan and Its Implications on the Geodynamic Evolution of the Dead Sea Shear Zone,” Atti die Convegni Lincei, Vol. 47, 1979, pp. 667-683.

[31] K. M. Ibrahim, K. Tarawneh and I. Rabba, "Phases of Activity and Geochemistry of Basaltic Dike System in Northeast Jordan Parallel to the Red Sea," Journal of Asian Sciences, Vol. 21, 2003, pp. 467-472.

[32] D. T. Moffat, “A Volcaotectonic Analysis of the Cenozoic Continental Basalts of Northern Jordan; Implications 
for Hydrocarbon Prospecting in the Block. B Area,” ERI Jordan, Amman, 1988.

[33] V. E. Camp and M. J. Roobol, "Upwelling Asthenosphere Beneath Western Arabia and Its Regional Implications," Journal of Geophysical Research, Vol. 97, No. B11, 1992, pp. 255-271. http://dx.doi.org/10.1029/92JB00943

[34] K. Tarawneh, S. Ilani, I. Rabba, Y. Harlavan, S. Peltz, K. Ibrahim, R. Weinberger and G. Steinitz, "Dating of the Harat Ash Shaam Basalt Northeast Jordan,” Report GSI/ 2/2000. Jordan, Natural Resources Authority (NRA), and Geological Survey of Israel, Jerusalem, 2000.

[35] S. Ilanis, Y. Harlavaa, K. Tarawneh, I. Rabba, R. Weinberger, K. Ibrahim, S. Peltz and G. Stttteinitz, "New K-Ar Ages of Basalts from the Harat Ash Shaam Volcanic Field in Jordan: Implications for the Span and Duration of the Upper Mantle Upwelling Beneath the Western Arabian Plate," Geology, Vol. 29, No. 2, 2001, pp. 171-174. http://dx.doi.org/10.1130/0091-7613(2001)029<0171:NK AAOB $>2.0 . \mathrm{CO} ; 2$

[36] A. Frumkin, M. Bar-Matthews and A. Vaks, "Paleoenvirnoment of Jawa Basalt Pleateau, Jordan, Inferred from Calcite Speleoyherms from a Lava Tube,” Quaternary Research, Vol. 70, No. 3, 2008, pp. 358-367. http://dx.doi.org/10.1016/j.yqres.2008.06.004

[37] I. Guba and H. Mustafa, "Structural Control of Young Basaltic Fissure Eruption in the Plateau Basalt Area of the Arabian Plate, Northeastern Jordan," Journal of Volcanology and Geothermal Research, Vol. 35, No. 4, 1988, pp. 319-334. http://dx.doi.org/10.1016/0377-0273(88)90026-1

[38] K. M. Ibrahim, “The Geological Framework for the Harrat Asham Basalt Super-Group and Its Volcaotectonic Evolution,” Natural Resources Authority, Geological Mapping Division, Jordan, Vol. 25, 1993, p. 33.

[39] K. M. Ibrahim, "The Regional Geology of Al-Azraq Area,” Natural Resources Authority, Geological Mapping Division, Jordan, Vol. 36, 1996, p. 67.

[40] K. Tarawneh, "Wadi Al-Abid Geological Map, Scale 1:50,000,” Natural Resources Authority, Geological Mapping Division, Amman, Jordan, 1999.

[41] K. Tarawneh, “The Geology of Wadi Al-Abid Area,” Natural Resources Authority, Geological Mapping Division, Amman, Jordan, Vol. 44, 1999.

[42] I. Rabba' and K. M. Ibrahim, “The Geological Map of Tlul Esh Shahba, Scale 1:100,000,” Natural Resources Authority, Geological Mapping Division, Amman, Jordan, 2005.

[43] D. V. Hills and S. E. Haggerty, "Petrochemistry of Eclogites from the Koida Kimberlite Complex, Sierra Leone," Contributions to Mineralogy and Petrology, Vol. 103, No. 4, 1989, pp. 397-422. http://dx.doi.org/10.1007/BF01041749

[44] A. T. Fung and E. H. Stephen, "Petrography and Mineral Compositions of Eclogites," Journal of Geophysical Research, Vol. 100, No. B10, 1995, pp. 20451-20473. http://dx.doi.org/10.1029/95JB01573

[45] W. D. Carlson and C. D. Johnson, "Coronal Reaction Textures in Garnet Amphibolites of the Llano Uplift,"
American Mineralogist, Vol. 76, 1991, pp. 756-772.

[46] K. Cornelis, “Manual of Mineralogy,” 20th Edition, John Wiley and Sons, Hoboken, 1980, p. 596.

[47] D. Perkins, “Mineralogy,” 2nd Edition, Prentice Hall, Inc. Upper Saddle River, 2002, p. 483.

[48] K. Collers, S. Hapagoda, B. Kamber and Q. William, "Rocks from the Mantle Transition Zone: Majorite-Bearing Xenoliths from Malaita, Southwest Pacific,” Science, Vol. 288, No. 5469, 2000, pp. 1215-1223.

[49] M. Obata and K. Ozawa, "Topotaxic Relationships between Spinel and Pyroxene in Kelyphite after Garnet in Mantle-Derived Peridotites and Their Implications to Reaction Mechanism and Kinetics," Mineralogy and Petrology, Vol. 101, No. 3-4, 2011, pp. 217-224. http://dx.doi.org/10.1007/s00710-011-0145-y

[50] M. Operta, S. Hyseni, D. Balen, S. Salihovic and B. Durmishaj, "Garnet Group Minerals from the Amphibolite Facies Metamorphic Rocks of Krivaja-Konjuh Ultramafic Massif Bosnia and Herzegovina," ARPN Journal of Engineering and Applied Sciences, Vol. 6, No. 7, 2011, pp. 20-28.

[51] M. Obata, "Material Transfer and Local Equilibria in a Zoned Kelyphite from a Garnet Pyroxenite, Ronda Spain," Journal of Petrology, Vol. 35, No. 1, 1994, pp. 271-287. http://dx.doi.org/10.1093/petrology/35.1.271

[52] J. Dégi, R. Abart, T. Kalman, E. Bali, R. Wirth and D. Rhede, "Symplectite Formation during Decompression Induced Garnet Breakdown in Lower Crustal Mafic Granulite Xenoliths: Mechanisms and Rates,” Contributions to Mineralogy and Petrology, Vol. 159, No. 3, 2010, pp. 293-314. http://dx.doi.org/10.1007/s00410-009-0428-z

[53] M. J. Le Bas, R. W. Le Maitre, A. Streckeisen and B. Zanettin, "A Chemical of Volcanic Rocks Based on the Total Alkali-Silica Diagram,” Journal of Petrology, Vol. 27, No. 3, 1986, pp. 745-750. http://dx.doi.org/10.1093/petrology/27.3.745

[54] R. B. Luth, D. Virgo, F. Boyd and B. J. Wood, "Ferric Iron in Mantle-Derived Garnets," Contributions to Mineralogy and Petrology, Vol. 104, No. 1, 1990, pp. 56-72. http://dx.doi.org/10.1007/BF00310646

[55] I. Kosa, "Genetic Significance of Garnets from the Visegrad Mts. and the Adjacent Volcanic Areas,” M.Sc. Thesis, ELTE Közettani-Geokémiai Tanszék, Budapest, 1998, p. 100.

[56] R. N. Thompson, "Is Upper-Mantle Phosphorus Contained in Sodic Garnet," Earth and Planetary Science Letters, Vol. 26, No. 3, 1975, pp. 417-424. http://dx.doi.org/10.1016/0012-821X 75 90017-5

[57] F. C. Bishop, J. V. Smith and B. J. Dawson, "Na, P, Ti and Coordination of Si in Garnet from Peridotite and Eclogite Xenoliths,” Nature, Vol. 260, 1976, pp. 696-697. http://dx.doi.org/10.1038/260696a0

[58] F. C. Bishop, J. V. Smith and B. J. Dawson, "Na, K, P and $\mathrm{Ti}$ in Garnet, Pyroxene and Olivine from Peridotite and Eclogite Xenoliths from African Kimberlites,” Lithos, Vol. 11, No. 2, 1978, pp. 155-173. http://dx.doi.org/10.1016/0024-4937 78 90006-3

[59] A. M. Reid, R. W. Brown, J. B. Dawson, G. Whitfield 
and J. Siebert, "Garnet and Pyroxene Compositions in Som Diamondiferous Eclogites,” Contribution Mineral Petrology, Vol. 58, No. 2, 1976, pp. 203-220. http://dx.doi.org/10.1007/BF00382185

[60] S. Haggerty, A. Fung and D. Burt, “Apatite, Phosphorous, and Titanium in Eclogitic Garnets in the Upper Mantle," Geophysical Research Letters, Vol. 21, No. 16, 1994, pp. 1699-1702. http://dx.doi.org/10.1029/94GL01001

[61] R. P. Tollo, "Petrography and Chemistry of Ultramafic and Related Inclusion from the Orapa A/K-1 Kimberlite pipe, Botswana,” Geology Master's Thesis, University of Mass, Amherst, 1982, p. 203.

[62] L. C. Kuo and E. J. Essene, "Petrology of Spinel Harzburgite Xenoliths from the Kishb Plateau, Saudi Arabia,” Mineralogy and Petrology, Vol. 93, No. 3, 1986, pp. 335346. http://dx.doi.org/10.1007/BF00389392

[63] A. V. Mc Guire, "The Mantle beneath the Red Sea Margin: Xenoliths from Western Saudi Arabia," Tectonophysics, Vol. 150, No. 1-2, 1988, pp. 101-119. http://dx.doi.org/10.1016/0040-1951 88 90297-1

[64] A. V. Mc Guire, "Petrology of Mantle Xenoliths from Harrat Al Kishb: The MANTLE beneath Western Saudi Arabia,” Journal of Petrology, Vol. 29, No. 1, 1988, pp. 73-92. http://dx.doi.org/10.1093/petrology/29.1.73

[65] J. Blusztajn, S. R. Hart, N. Shimizu and A. V. McGuire, "Trace-Element and Isotopic Characteristics of Spinel Pe- ridotite Xenoliths from Saudi Arabia,” Chemical Geology, Vol. 123, No. 1-4, 1995, pp. 53-65.

http://dx.doi.org/10.1016/0009-2541 95 00044-M

[66] S. Nasir and A. Safarjalani, "Lithospheric Petrology beneath the Northern Part of the Arabian Plate in Syria: Evidence from Xenoliths in Alkali Basalts,” Journal of African Earth Sciences, Vol. 30, No. 1, 2000, pp. 149-168. http://dx.doi.org/10.1016/S0899-5362 $0000013-0$

[67] S. Nasir, "The Lithosphere beneath the Northwestern Part of the Arabian Plate Jordan: Evidence from Xenoliths and Geophysics,” Tectonophysics, Vol. 201, No. 3-4, 1992, pp. 357-370. http://dx.doi.org/10.1016/0040-1951 92 90242-X

[68] Z. El-Isa, J. Mechie, C. Prodehl, J. Makris and R. Rihm, "A Crustal Structure Study of Jordan Derived from Seismic Refraction Data,” Tectonophysics, Vol. 138, No. 2-4, 1987, pp. 235-253. http://dx.doi.org/10.1016/0040-1951 87 90042-4

[69] S. Nasir, "Mafic Lower Crustal Xenoliths from the Northwestern Part of the Arabian Plate,” European Journal of Mineralogy, Vol. 7, No. 1, 1995, pp. 217-230.

[70] I. Bany Yaseen, Z. Al-Hawari and A. Diabat, "Petrology, Geochemistry, Petrogenesis and Reactivation of Volcanic tuffs at Dair El-Kahif, NE Jordan," Jordan Journal of Civil Engineering, Vol. 4, No. 4, 2010, pp. 336-350. 